\title{
Effects of corn feeding reduced-fat distillers grains with or without monensin on nitrogen, phosphorus, and sulfur utilization and excretion in dairy cows
}

\author{
D. L. Morris, S. H. Kim, and C. Lee ${ }^{1}$ \\ Department of Animal Sciences, Ohio Agricultural Research and Development Center, The Ohio State University, Wooster 44691
}

\begin{abstract}
This study investigated effects of high inclusion of reduced-fat corn distillers grains with solubles (RFDG) with or without monensin on utilization and excretion of dietary N, P, and S. The experiment was conducted for 11 wk (2-wk diet adaptation, 9-wk experimental period of data collection) with 36 Holstein cows in a randomized complete block design. Cows were blocked by parity, days in milk, and milk yield and assigned to the following diets: (1) a control diet $(\mathrm{CON}) ;(2) \mathrm{CON}$ with RFDG included at $28.8 \%$ (dry matter basis) by replacing soybean meal, soyhulls, and supplemental fat and phosphorus (DG); and (3) DG with monensin (Rumensin; Elanco Animal Health, Greenfield, IN) supplemented at a rate of $20 \mathrm{mg} / \mathrm{kg}$ of DM offered (DGMon). Contrasts were used to compare CON versus DG and DG versus DGMon. Inclusion of RFDG at $28.8 \%$ of dietary DM replacing mainly soybean meal did not change crude protein content (17.6\% on a DM basis) but decreased rumen-degradable protein and increased rumen-undegradable protein. In addition, the DG diets increased $\mathrm{P}(0.48$ vs. $0.36 \%)$ and $\mathrm{S}$ concentrations (0.41 vs. $0.21 \%$; DM basis) compared with the CON diet. As a result, DG versus CON decreased plasma and milk urea $\mathrm{N}$ concentrations and urinary $\mathrm{N}$ excretion. However, the increase in $\mathrm{P}$ concentration when feeding the DG versus CON diet to lactating cows increased $\mathrm{P}$ intake, plasma $\mathrm{P}$ concentration, and urinary and fecal $\mathrm{P}$ excretion without affecting milk $\mathrm{P}$ secretion. Intake of $\mathrm{S}$ was greater for cows fed the DG versus CON diet, resulting in greater plasma total $\mathrm{S}$ and sulfate concentration and urinary and fecal $\mathrm{S}$ excretion. However, milk S secretion was not affected by DG compared with CON. Monensin supplementation to the DG diet did not affect $\mathrm{N}$ intake, utilization, and excretion except that apparent $\mathrm{N}$ digestibility was lower compared with DG. In addition, feeding the DGMon diet did not affect $\mathrm{P}$ and $\mathrm{S}$ utilization and excretion compared with
\end{abstract}

Received February 1, 2018.

Accepted April 17, 2018.

${ }^{1}$ Corresponding author: Lee.7502@osu.edu
DG. The study suggests that inclusion of high RFDG in a ration by replacing mainly soybean meal altered $\mathrm{N}, \mathrm{P}$, and $\mathrm{S}$ utilization and excretion, but monensin supplementation to a high-RFDG diet, overall, had minimal effects on $\mathrm{N}, \mathrm{P}$, and $\mathrm{S}$ utilization and excretion in lactating dairy cows.

Key words: reduced-fat distillers grains, monensin, dairy cows

\section{INTRODUCTION}

Ethanol production continues to increase, resulting in increased production of corn dried distillers grain with solubles (DDGS; Renewable Fuels Association, 2017), which has been widely used as an animal feed. More recently, DDGS with less fat content, reduced-fat DDGS (RFDG), has increased in availability and can be used as an animal feed. According to multiple studies with dairy cows, up to $30 \%$ (DM basis) RFDG can be included in dairy rations without negatively affecting DMI, milk yield, and milk composition (Mjoun et al., 2010b; Castillo-Lopez et al., 2014; Ramirez-Ramirez et al., 2016). However, due to the high concentration of certain nutrients in RFDG, such as RUP, $\mathrm{P}$, and S, feeding a diet with high RFDG may cause environmental concerns by increasing the excretion of those nutrients. However, studies about utilization and excretion of N, $\mathrm{P}$, and $\mathrm{S}$ when dairy cows are fed high-RFDG diets are scarce $(\mathrm{N})$ or not available (P and $\mathrm{S})$.

An in situ and in vitro study by Mjoun et al. (2010a) indicated that intestinal digestibility and total digestible (i.e., RDP plus digested RUP) is less for RFDG compared with soybean meal (SBM); therefore, $\mathrm{N}$ utilization for milk and urinary $\mathrm{N}$ excretion could decrease and fecal $\mathrm{N}$ excretion increase when feeding RFDG versus SBM. Furthermore, the concentration of $\mathrm{P}$ and $\mathrm{S}$ in SBM is about 0.7 and $0.4 \%$, respectively (NRC, 2001 ), whereas the $\mathrm{P}$ and $\mathrm{S}$ content of RFDG is 0.8 to $0.9 \%$ and 0.7 to $1.2 \%$, respectively (DuFour, 2017). Therefore, increased dietary inclusion of RFDG can increase dietary $\mathrm{P}$ and $\mathrm{S}$ content, resulting in increased excretion of $\mathrm{P}$ and $\mathrm{S}$. Inclusion of RFDG at about $30 \%$ of diet DM increased dietary $\mathrm{P}$ content from 0.36 to 
0.52\% (Castillo-Lopez et al., 2014) and S content from 0.25 to $0.53 \%$ (Ramirez-Ramirez et al., 2016). Manure with high $\mathrm{P}$ concentration has potential for $\mathrm{P}$ losses (e.g., runoff) when the manure is applied to the field (Hanrahan et al., 2009). Manure with high S concentration can negatively affect public perception and human and animal health (e.g., odor and toxicity of Scontaining gas to animals and humans; Guidotti, 2010). Due to increased dietary S content with high-RFDG diets, $\mathrm{S}$ excretion can increase, potentially resulting in increased hydrogen sulfide $\left(\mathrm{H}_{2} \mathrm{~S}\right)$ emissions from manure, especially when manure is mixed and pumped out (Andriamanohiarisoamanana et al., 2015). However, excretion of $\mathrm{P}$ and $\mathrm{S}$ has been rarely considered when the inclusion rate of RFDG in a ration is determined.

Monensin is a commonly used feed additive in the dairy industry and has been shown to increase $\mathrm{N}$ utilization efficiency (Plaizier et al., 2000; Ruiz et al., 2001; Martineau et al., 2007). Increased apparent absorption and retention of certain minerals, including $\mathrm{P}$, were also observed when monensin was fed to beef cattle and sheep (Starnes et al., 1984; Greene et al., 1986). Furthermore, monensin can alter ruminal S metabolism by altering rumen microbial communities. As an example, monensin supplementation to a diet containing DDGS in beef cattle decreased ruminal $\mathrm{H}_{2} \mathrm{~S}$ in some (Felix and Loerch, 2011) but not all studies (Felix et al., 2012). Therefore, monensin supplementation to a high-RFDG diet has potential to alter $\mathrm{N}, \mathrm{P}$, and $\mathrm{S}$ utilization and excretion in dairy cows. Although monensin and RFDG are a widely used feed additive and ingredient for dairy cows, few studies have examined N, P, and S utilization in terms of environmental impacts.

The objectives of our study were to assess the effect of feeding RFDG with or without monensin on N, $\mathrm{P}$, and $\mathrm{S}$ utilization and excretion in dairy cattle. Our hypotheses were (1) feeding RFDG decreases urinary $\mathrm{N}$ excretion but increases fecal and urinary $\mathrm{P}$ and $\mathrm{S}$ excretion, and (2) monensin supplementation to a highRFDG diet will decreases $\mathrm{N}$ and $\mathrm{P}$ excretion and alter $\mathrm{S}$ utilization and excretion.

\section{MATERIALS AND METHODS}

\section{Animals and Treatments}

Animal care and procedures were approved by The Ohio State University Institutional Animal Care and Use Committee. The cows used were not fed monensin for at least 6 mo before the experiment.

The experiment was carried out at the Ohio $\mathrm{Ag}$ ricultural Research and Development Dairy Center (Wooster, OH). Information about animals, experimental design, and dietary treatments were described in de- tail in our previous study (Morris et al., 2018). Briefly, 36 (9 primiparous and 27 multiparous) Holstein cows (average $\pm \mathrm{SD}$ at the beginning of the trial: milk yield $=44.2 \pm 8.1 \mathrm{~kg} / \mathrm{d} ; \mathrm{DIM}=80 \pm 31 \mathrm{~d} ; \mathrm{BW}=675 \pm 74$ $\mathrm{kg})$ were blocked into groups of $3(\mathrm{n}=12)$ by parity, DIM, and milk yield. Cows in each block were randomly allocated to 1 of 3 treatment diets (a randomized complete block design): (1) control diet (CON; a typical lactating cow ration; Table 1); (2) the CON with RFDG included at $28.8 \%$ of diet DM replacing SBM, soyhulls and supplemental fat (DG); and (3) the DG diet with monensin (Rumensin; Elanco Animal Health, Greenfield, IN) supplemented at a rate of $20 \mathrm{mg} / \mathrm{kg}$ of DM offered (DGMon). For the DG diets (i.e., DG and DGMon), RFDG fully replaced SBM, soyhulls, and supplemental fat and calcium phosphate. All diets were formulated to be isoenergetic and isonitrogenous and to meet or exceed nutrient requirements according to NRC (2001). Supplemental P (i.e., calcium phosphate) was removed from the DG diets to minimize $\mathrm{P}$ overfeeding. Although this resulted in a decrease in dietary $\mathrm{Ca}$ content in the DG diets (Table 1), Ca supply exceeded NRC (2001) requirements. Further information about dietary composition is available in our previous study (Morris et al., 2018). The experiment consisted of a diet adaptation period for $2 \mathrm{wk}$ and a 9 -wk experimental period (wk 1 through 9 refers to the 9 -wk experimental period). During the first week of the diet adaptation, the inclusion rate of monensin for DGMon was half of the target rate (i.e., $10 \mathrm{mg} / \mathrm{kg}$ of $\mathrm{DM}$ ) and it was increased to $20 \mathrm{mg} / \mathrm{kg}$ of DM at the start of wk 2 . Cows were housed in individual tiestalls with free access to water and milked twice a day. All diets were prepared daily and fed as TMR once a day with a target refusal rate of $5 \%$.

\section{Sample Collection}

Animals were sampled during wk 1, 5, and 9. During the first $3 \mathrm{~d}$ of sampling week, spot fecal and urine samples (from the rectum and by massaging the vulva, respectively) were collected every $9 \mathrm{~h}$, yielding 8 samples representing every $3 \mathrm{~h}$ in a 24 -h period. Samples were composited on an equal volume basis during collection and frozen $\left(-20^{\circ} \mathrm{C}\right)$ between sampling events until later analysis. Urine samples were acidified with 2 $M \mathrm{HCl}$ to maintain a $\mathrm{pH}<3.0$. During fecal and urine sampling (first $3 \mathrm{~d}$ of wk 1, 5, and 9), feeds offered and refused were monitored, sampled, and composited and feed ingredients; refusal samples were collected for the $3 \mathrm{~d}$ and composited by week for feeds and by cow and week for refusals (on a weight basis). In addition, individual cows were weighed for 2 consecutive days in wk 1, 5, and 9 (4 to $6 \mathrm{~h}$ after feeding). Therefore, feed 
MORRIS ET AL.

Table 1. Dietary ingredients and chemical composition ( $\%$ of DM $)^{1}$

\begin{tabular}{|c|c|c|c|}
\hline Item & $\mathrm{CON}$ & DG & DGMon \\
\hline \multicolumn{4}{|l|}{ Ingredient } \\
\hline Corn silage & 41.6 & 41.6 & 41.6 \\
\hline Alfalfa silage & 9.7 & 9.7 & 9.7 \\
\hline Alfalfa hay & 5.0 & 5.0 & 5.0 \\
\hline $\mathrm{RFDG}^{2}$ & - & 28.8 & 28.8 \\
\hline Corn grain, ground & 12.9 & 13.2 & 13.2 \\
\hline Soybean meal $48 \%$ & 15.1 & - & - \\
\hline Soyhulls & 12.3 & - & - \\
\hline $\mathrm{Fat}^{3}$ & 1.34 & - & - \\
\hline Calcium phosphate & 0.23 & - & - \\
\hline Mineral/vitamin $\operatorname{mix}^{4}$ & 1.73 & 1.73 & 1.73 \\
\hline Monensin ${ }^{5}$ & - & - & 0.01 \\
\hline \multicolumn{4}{|c|}{ Chemical composition (average $\pm \mathrm{SD}$ ) } \\
\hline $\mathrm{CP}$ & $17.6 \pm 0.7$ & $17.7 \pm 0.3$ & $17.4 \pm 0.1$ \\
\hline $\mathrm{RDP}^{6}$ & 10.7 & 9.9 & 9.8 \\
\hline RUP $^{6}$ & 7.0 & 7.8 & 7.6 \\
\hline $\mathrm{Ca}$ & $0.72 \pm 0.02$ & $0.61 \pm 0.01$ & $0.61 \pm 0.03$ \\
\hline $\mathrm{P}$ & $0.36 \pm 0.01$ & $0.48 \pm 0.02$ & $0.47 \pm 0.01$ \\
\hline $\mathrm{Mg}$ & $0.22 \pm 0.01$ & $0.25 \pm 0.01$ & $0.24 \pm 0.00$ \\
\hline $\mathrm{K}$ & $1.64 \pm 0.04$ & $1.45 \pm 0.04$ & $1.44 \pm 0.03$ \\
\hline $\mathrm{S}$ & $0.21 \pm 0.01$ & $0.41 \pm 0.01$ & $0.41 \pm 0.02$ \\
\hline $\mathrm{Na}$ & $0.30 \pm 0.03$ & $0.38 \pm 0.05$ & $0.43 \pm 0.07$ \\
\hline $\mathrm{Cl}$ & $0.81 \pm 0.01$ & $0.77 \pm 0.09$ & $0.80 \pm 0.09$ \\
\hline \multicolumn{4}{|c|}{$\begin{array}{l}{ }^{1} \mathrm{CON}=\text { control diet; } \mathrm{DG}=\text { diet containing } 28.8 \% \text { RFDG }(\mathrm{DM} \text { basis); DGMon }=\mathrm{DG} \text { with monensin at } 20 \\
\mathrm{mg} / \mathrm{kg} \text { of DM. }\end{array}$} \\
\hline \multirow{2}{*}{\multicolumn{4}{|c|}{$\begin{array}{l}{ }^{2} \mathrm{RFDG}=\text { reduced-fat distillers grains (POET Nutrition Inc., Sioux Falls, SD). } \\
{ }^{3} \text { Energy Booster } 100 \text { (Hubbard Feeds, Mankato, MN). }\end{array}$}} \\
\hline & & & \\
\hline \multicolumn{4}{|c|}{$\begin{array}{l}{ }^{4} \text { Contained } 488 \mathrm{~g} \text { of trace mineral salt, } 377 \mathrm{~g} \text { of limestone, } 1,331 \mathrm{mg} \text { of zinc (from Zinpro 120; Zinpro Coporation, } \\
\text { Eden Prairie, MN), } 559 \mathrm{mg} \text { of copper (from copper sulfate), } 13 \mathrm{mg} \text { of selenium (from sodium selenate), and } \\
1,269 \mathrm{kIU} \text { of vitamin E, } 253 \mathrm{kIU} \text { of vitamin A, } 53 \mathrm{kIU} \text { of vitamin D per kg of premix. }\end{array}$} \\
\hline \multicolumn{4}{|c|}{${ }^{5}$ Monensin (Rumensin 90; Elanco Animal Health, Greenfield, IN). } \\
\hline${ }^{6}$ Estimated according to & & & \\
\hline
\end{tabular}

intakes and BW of individual animals observed during the sampling week were used for calculations of nutrient utilization and excretion.

Milk samples were collected for 4 consecutive milkings on $\mathrm{d} 2$ and 3 of each sampling week (wk 1, 5, and 9 ), composited by cow and week and frozen at $-20^{\circ} \mathrm{C}$ until later analysis. Blood samples were collected approximately $4 \mathrm{~h}$ after feeding during $\mathrm{d} 4$ and 5 in wh 1 , 5 , and 9 into evacuated lithium heparin tubes by coccygeal venipuncture. Plasma was immediately separated by centrifugation at $3,000 \times g$ for $15 \mathrm{~min}$ at $4^{\circ} \mathrm{C}$ and frozen at $-20^{\circ} \mathrm{C}$ until later analysis.

\section{Sample Analysis}

Silage, refusals, and fecal samples were dried $\left(55^{\circ} \mathrm{C}\right.$ for $72 \mathrm{~h}$ ) and ground to pass a 1-mm screen (Wiley Mill; Arthur H. Thomas Co., Philadelphia, PA). Dried and ground feed, refusals, and fecal samples were analyzed for analytical DM (AOAC International, 2000; method $934.01 ; 100^{\circ} \mathrm{C}$ overnight), ash (AOAC International, 2000; method $942.05 ; 600^{\circ} \mathrm{C}$ overnight), N (Elemental Analyzer; Flash 2000; Thermo Fisher Sci- entific, Waltham, MA ), NDF (Ankom200 Fiber Analyzer; Ankom Technology Corp., Fairport, NY), and minerals (Service Testing and Research Laboratory, Ohio Agricultural Research and Development Center, Wooster, $\mathrm{OH}$ ) using inductively coupled plasma emission spectroscopy (Isaac and Johnson, 1985) after microwave digestion with nitric acid (Jones et al., 1991). In addition, all feeds, refusals, and feces were analyzed for indigestible NDF as described by Lee et al. (2012). Briefly, samples were weighed in quadruplicate into filter bags (25- $\mu \mathrm{m}$ pore size; Ankom Technology Corp.) and incubated in 2 cannulated, lactating Holstein cows for $12 \mathrm{~d}$. After incubation, bags were rinsed until water ran clear and analyzed for NDF (Ankom200 Fiber Analyzer; Ankom Technology Corp.). Fecal excretion was estimated using indigestible NDF intake and fecal content.

Urine samples were analyzed for N (Flash 2000; Thermo Fisher Scientific), creatinine (kit 500701; Cayman Chemical, Ann Arbor, MI), urea N (UUN; kit UR107; Randox Laboratories Ltd., Crumlin, United Kingdom), and minerals (Service Testing and Research Laboratory, OARDC, Wooster, OH). Urine excretion 
was estimated based on urinary creatinine concentration assuming a creatinine excretion rate of $29.0 \mathrm{mg} / \mathrm{kg}$ of BW (Valadares et al., 1999).

Plasma was analyzed for plasma urea N (PUN; kit UR107; Randox Laboratories Ltd.), total minerals as for urine, and inorganic P (kit 0830-125; Stanbio Laboratories, Boerne, TX). Plasma sulfate was determined using ion chromatography (Service Testing and Research Laboratory, OARDC, Wooster, OH) after protein precipitation with acetonitrile.

Milk samples were analyzed for N (Flash 2000; Thermo Fisher Scientific), MUN (Skalar SAN Plus segmented flow analyzer, Skalar Inc., Norcross, GA) by DHI Cooperative Inc. (Columbus, OH), and minerals as described for urine.

\section{Statistical Analysis}

One cow on the DG treatment was removed from the trial at the end of wk 8 due to a displaced abomasum. Data were analyzed in R (v3.4.1) using the linear and nonlinear mixed effects models (v3.1-131) package (Pinheiro et al., 2017). All data were analyzed using an autoregressive first-order covariance structure selected according to lowest Bayesian information criterion. The model included the fixed effects of treatment, week, and the interaction of treatment and week, and the random effect of block, cow within block, and error. Significant interactions of dietary treatments by week were presented when overall dietary effects were significant. Residuals for all variables were visually analyzed for homogeneity and normality and all were found to meet the assumptions of ANOVA. All data including graphs are presented as least squares means \pm largest standard error of the mean, unless noted otherwise. Contrasts were used to evaluate the effects of RFDG and monensin. Significance was declared at $P \leq 0.05$ and trends are discussed at $0.05<P \leq 0.10$.

\section{RESULTS AND DISCUSSION}

The RFDG used in the current experiment contained $34.4 \%$ CP, $27.5 \%$ NDF, $7.4 \%$ ether extract, $0.91 \%$ P, and $0.92 \% \mathrm{~S}$ on a DM basis. Although $\mathrm{CP}$ content was similar between diets, estimated RDP content (NRC, 2001) was lower and RUP was greater for DG and DGMon compared with CON (Table 1). Additionally, although supplemental $\mathrm{P}$ was removed from the DG diets, $\mathrm{P}$ content was greater $(0.48$ vs. $0.36 \%)$ for $\mathrm{DG}$ and DGMon compared with CON. Inclusion of RFDG at $28.8 \%$ of diet DM increased (0.41 vs. $0.21 \%$ ) dietary S content compared with CON. In agreement, increased RUP, $\mathrm{P}$, and $\mathrm{S}$ in diets containing high RFDG have been observed (Castillo-Lopez et al., 2014; RamirezRamirez et al., 2016).

\section{Fecal and Urine Outputs}

Fecal output (DM basis) did not differ $(P \geq 0.13)$ among treatments. However, feeding DG compared with CON decreased $(P=0.04)$ urine outputs by $15 \%$ without a difference between DG and DGMon (Table 2 ). We found no changes in fecal output when cows were fed diets containing up to 30\% (DM basis) RFDG (Castillo-Lopez et al., 2014); however, a decrease in urinary output for cows fed DG versus CON was not expected. High inclusion of wheat (Li et al., 2014) and corn DDGS (Salim et al., 2012) in a ration increased urinary excretion in beef cattle. Li et al. (2014) demonstrated that increases in dietary DDGS can increase water consumption and, thus, increase urinary excretion. In the current study, although certain dietary minerals, such as P, S, and Na, were increased, dietary $\mathrm{K}$ concentration decreased. Dietary K concentration has been known to increase urine output (Weiss et al., 2009; Eriksson and Rustas, 2014). Furthermore, MUN was greater for cows fed CON than RFDG, and MUN is positively correlated with urine output (Nennich et al., 2006).

\section{Nitrogen Utilization and Excretion}

Intake of $\mathrm{N}$ did not differ among treatments (Table 3). Fecal $\mathrm{N}$ excretion, fecal $\mathrm{N}$ excretion as a proportion of $\mathrm{N}$ intake, and apparent $\mathrm{N}$ digestibility (Table 4) were not different $(P \geq 0.65)$ for cows fed DG compared with CON. However, urinary $\mathrm{N}$ excretion decreased ( $P$ $\leq 0.04$ ) by $9 \%$, whereas retained $\mathrm{N}$ tended to be greater $(28$ vs. $3 \mathrm{~g} / \mathrm{d} ; P=0.07)$ for the DG diet versus CON. Urinary urea $\mathrm{N}$ excretion decreased $(P=0.03)$ by $12 \%$ for when feeding DG compared with CON. Milk urea $\mathrm{N}$ and PUN concentrations were also lower $(P<0.01$; Table 5) in cows fed DG compared with CON. The DGMon diet did not affect $\mathrm{N}$ excretion and secretion except that DGMon decreased $(P=0.04)$ fecal $\mathrm{N}$ as a proportion of $\mathrm{N}$ intake (i.e., increased apparent $\mathrm{N}$ digestibility) compared with DG.

An increase in fecal $\mathrm{N}$ excretion was expected because of high RUP of RFDG protein compared with SBM protein. However, in situ and in vitro results by Mjoun et al. (2010a) indicated that total digestible protein (rumen and small intestine) between RFDG and SBM was similar (95 and 99\%, respectively) in spite of different RUP (32 vs. 60\%, respectively). This may have resulted in minimal effects on apparent total-tract $\mathrm{N}$ digestibility in cows fed either the DG or CON diet. 
Table 2. Effects of feeding reduced-fat corn distillers grains (RFDG) with or without monensin on DMI and feces, urine, and milk outputs $(\mathrm{kg} / \mathrm{d})^{1}$

\begin{tabular}{|c|c|c|c|c|c|c|}
\hline \multirow[b]{2}{*}{ Item } & \multicolumn{3}{|c|}{$\operatorname{Diet}^{2,3}$} & \multirow[b]{2}{*}{ SEM } & \multicolumn{2}{|c|}{$P$-value ${ }^{4}$} \\
\hline & $\mathrm{CON}$ & DG & DGMon & & DG & Mon \\
\hline$\overline{\mathrm{DMI}}$ & 26.0 & 25.4 & 24.4 & 0.89 & 0.57 & 0.39 \\
\hline Milk & 40.6 & 42.3 & 38.5 & 2.21 & 0.37 & 0.051 \\
\hline Feces (DM basis) & 7.6 & 8.1 & 7.3 & 0.34 & 0.34 & 0.13 \\
\hline Urine & 32.5 & 27.7 & 29.7 & 1.76 & 0.04 & 0.39 \\
\hline
\end{tabular}

${ }^{1}$ During wk 1, 5, and 9 sampling collection periods.

${ }^{2} \mathrm{CON}=$ control diet; $\mathrm{DG}=$ diet containing $28.8 \%$ RFDG $(\mathrm{DM}$ basis $)$; DGMon = DG with monensin at 20 $\mathrm{mg} / \mathrm{kg}$ of DM.

${ }^{3}$ Least squares means; largest SE of treatment mean is shown.

${ }^{4} \mathrm{DG}=\mathrm{CON}$ vs. DG; Mon $=$ DG vs. DGMon.

In agreement with our results, no differences in fecal $\mathrm{N}$ outputs were observed with $25 \%$ (DM basis) wet distillers grains or $28.8 \%$ RFDG in dairy rations (Gehman and Kononoff, 2010; Foth et al., 2015). Decreases in urinary $\mathrm{N}$ and UUN excretion for DG compared with CON occurred due to lower ruminal degradation of RFDG protein versus SBM protein (Mjoun et al., 2010a), which is in line with decreased MUN and PUN for DG compared with $\mathrm{CON}$ in the current study. Because UUN is the primary contributor to ammonia emissions from manure (Bussink and Oenema, 1998; Thomsen, 2000), feeding cows a diet with high RFDG replacing SBM can potentially decrease ammonia volatilization from manure. Compared with DG, DGMon did not affect most measures of $\mathrm{N}$ utilization and excretion. However, apparent total-tract $\mathrm{N}$ digestibility increased slightly (74.0 vs. 72.3; Table 4) with DGMon versus DG. Increased apparent $\mathrm{N}$ digestibility with monensin supplementation has often been reported in other studies (Plaizier et al., 2000; Ruiz et al., 2001; Martineau et al., 2007). Monensin inhibits AA-fermenting bacteria in the rumen (Chen and Russell, 1989), and thus increases dietary protein entering the small intestine. If dietary protein is more digestible than microbial protein, increases in dietary protein entering the small intestine should increase total-tract $\mathrm{N}$ digestibility (Martineau et al., 2007).

Interactions of treatment by week for urinary $\mathrm{N}$ and UUN excretion and PUN $(P \leq 0.02)$ were observed (Figure 1). The interactions occurred because these variables were similar among treatments in wk 1 and the differences in these among treatments became larger as

Table 3. Effects of feeding reduced-fat corn distillers grains (RFDG) with or without monensin on N utilization and excretion

\begin{tabular}{|c|c|c|c|c|c|c|}
\hline \multirow[b]{2}{*}{ Item } & \multicolumn{3}{|c|}{$\operatorname{Diet}^{1,2}$} & \multirow[b]{2}{*}{ SEM } & \multicolumn{2}{|c|}{$P$-value ${ }^{3}$} \\
\hline & $\mathrm{CON}$ & DG & DGMon & & DG & Mon \\
\hline $\mathrm{N}$ intake, $\mathrm{g} / \mathrm{d}$ & 722 & 718 & 684 & 26.4 & 0.92 & 0.35 \\
\hline \multicolumn{7}{|l|}{$\mathrm{N}$ secretion and excretion, $\mathrm{g} / \mathrm{d}$} \\
\hline Feces & 192 & 200 & 181 & 9.1 & 0.53 & 0.15 \\
\hline Urine $^{4}$ & 304 & 277 & 270 & 12.2 & 0.03 & 0.56 \\
\hline Urea $\mathrm{N}^{4}$ & 207 & 183 & 174 & 10.7 & 0.03 & 0.45 \\
\hline Urinary urea $\mathrm{N} /$ total N, \% & 68 & 66 & 64 & 1.3 & 0.22 & 0.24 \\
\hline Total excreta & 497 & 477 & 451 & 18.8 & 0.34 & 0.21 \\
\hline Milk & 223 & 214 & 205 & 9.2 & 0.32 & 0.33 \\
\hline Retained & 3 & 28 & 30 & 10.4 & 0.07 & 0.86 \\
\hline \multicolumn{7}{|l|}{ As proportion of $\mathrm{N}$ intake, $\%$} \\
\hline Feces & 26.6 & 27.7 & 26.1 & 0.52 & 0.15 & 0.04 \\
\hline Urine & 42.1 & 38.7 & 39.5 & 1.38 & 0.09 & 0.67 \\
\hline Total excreta & 68.6 & 66.4 & 65.7 & 1.25 & 0.21 & 0.66 \\
\hline Milk & 30.8 & 29.9 & 30.0 & 1.03 & 0.44 & 0.89 \\
\hline Retained & 0.5 & 3.7 & 4.3 & 1.62 & 0.13 & 0.79 \\
\hline MUN, mg/dL ${ }^{4}$ & 15.1 & 11.7 & 10.7 & 0.6 & $<0.01$ & 0.23 \\
\hline
\end{tabular}

${ }^{1} \mathrm{CON}=$ control diet; DG $=$ diet containing 28.8\% RFDG (DM basis); DGMon = DG with monensin at 20 $\mathrm{mg} / \mathrm{kg}$ of DM.

${ }^{2}$ Least squares means; largest SE of treatment mean is shown.

${ }^{3} \mathrm{DG}=\mathrm{CON}$ vs. DG; Mon $=$ DG vs. DGMon.

${ }^{4}$ Treatment $\times$ week interaction $(P \leq 0.02)$. 
Table 4. Effects of feeding reduced-fat corn distillers grains with solubles (RFDG) with or without monensin on apparent total-tract digestibility (\%)

\begin{tabular}{|c|c|c|c|c|c|c|}
\hline \multirow[b]{2}{*}{ Item } & \multicolumn{3}{|c|}{$\operatorname{Diet}^{1,2}$} & \multirow[b]{2}{*}{ SEM } & \multicolumn{2}{|c|}{$P$-value ${ }^{3}$} \\
\hline & $\mathrm{CON}$ & DG & DGMon & & DG & Mon \\
\hline$\overline{\mathrm{DM}}$ & 70.8 & 68.3 & 70.1 & 0.56 & 0.01 & 0.02 \\
\hline $\mathrm{OM}$ & 71.5 & 69.0 & 70.7 & 0.56 & $<0.01$ & 0.04 \\
\hline $\mathrm{NDF}^{4}$ & 53.5 & 47.4 & 50.4 & 0.93 & $<0.01$ & 0.03 \\
\hline $\mathrm{N}$ & 73.4 & 72.3 & 73.9 & 0.52 & 0.15 & 0.04 \\
\hline $\mathrm{P}^{4}$ & 49.7 & 43.9 & 44.7 & 2.14 & 0.06 & 0.78 \\
\hline $\mathrm{S}$ & 58.0 & 74.7 & 75.1 & 0.48 & $<0.01$ & 0.51 \\
\hline
\end{tabular}

the experiment progressed (wk 5 and 9), which was not expected and is difficult to explain. The second batch of RFDG for DG and DGMon was used from wk 5 to 9. Although CP contents of RFDG between the first and second batch were almost identical (34.22 vs. $34.60 \%)$, differences in processing method could have affected rumen protein property (e.g., RDP and RUP) and may have contributed to the treatment by week interactions. Additionally, microbial degradation of rumen protein and postabsorptive AA catabolism can contribute to urea production (Nousiainen et al., 2004). Therefore, protein catabolism pre- or postabsorption might change as lactation progressed (Larsen et al., 2015). However, milk protein production remained consistent throughout the experiment, which is shown in our companion study (Morris et al., 2018).

\section{Phosphorus Utilization and Excretion}

Intake of $\mathrm{P}$ increased $(122.6$ vs. $93.3 \mathrm{~g} / \mathrm{d} ; P<0.01)$ in cows fed DG compared with CON, resulting in increased $(P<0.01)$ fecal excretion and a tendency $(P$
$=0.054)$ for increased urinary $\mathrm{P}$ excretion (Table 6). However, milk $\mathrm{P}$ secretion did not differ $(P=0.58)$, resulting in decreased milk $\mathrm{P}$ as a proportion of $\mathrm{P}$ intake (32.4 vs. $43.3 \% ; P<0.01)$ for DG compared with CON. Feeding the DG diet compared with CON tended $(P=0.06)$ to decrease (43.9 vs. 49.7$)$ apparent totaltract $\mathrm{P}$ digestibility (Table 4$)$, but increased $(P<0.01)$ plasma total and inorganic $\mathrm{P}$ concentrations (Table 5). Monensin supplementation to the DG diet did not alter dietary $\mathrm{P}$ utilization and excretion.

Approximately $80 \%$ of the increased $\mathrm{P}$ intake by feeding the DG diet versus CON was partitioned toward fecal excretion. Feces are the primary route of dietary $\mathrm{P}$ excretion (Morse et al., 1992). A meta-analysis by Alvarez-Fuentes et al. (2016) showed a clear positive relationship between $\mathrm{P}$ intake and fecal $\mathrm{P}$ output in dairy cows. Increases in urinary $\mathrm{P}$ excretion for $\mathrm{DG}$ versus $\mathrm{CON}$ were also expected. Although the primary route of $\mathrm{P}$ excretion is feces, urinary $\mathrm{P}$ excretion increases when $\mathrm{P}$ intake exceeds requirements for maintenance and production (Knowlton and Herbein, 2002; Suttle and Underwood, 2010). Although plasma P concentra-

Table 5. Effects of feeding reduced-fat corn distillers grains with solubles (RFDG) with or without monensin on plasma urea, $\mathrm{P}$, and $\mathrm{S}$ concentrations $(\mathrm{mg} / \mathrm{dL})$

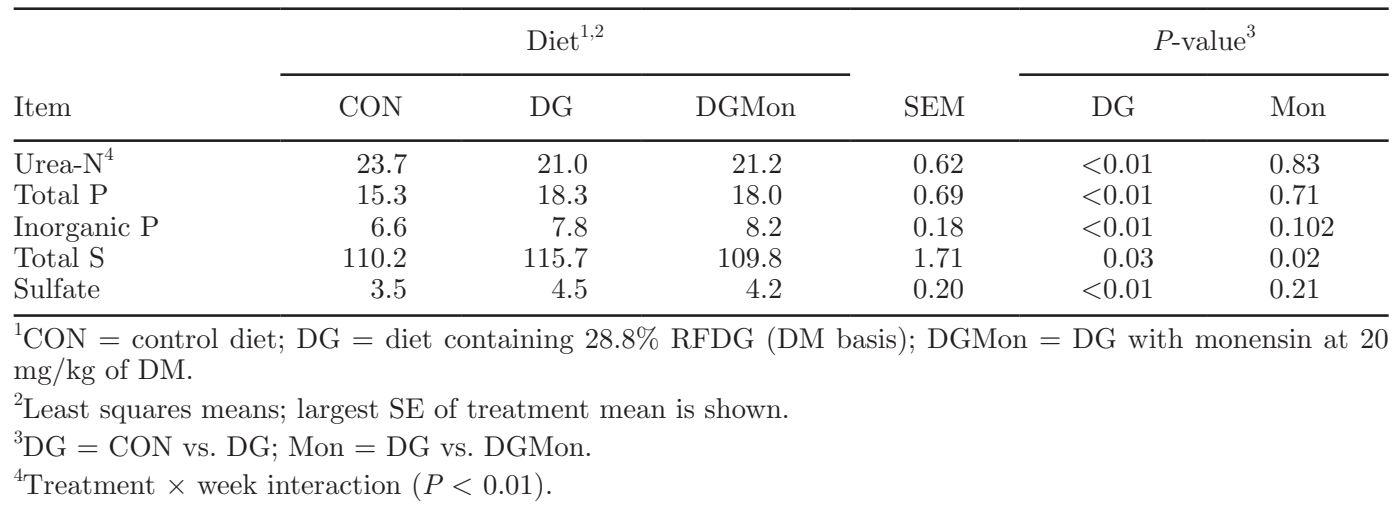




\section{CON $\bigcirc$ DG $\triangle$ DGMon}
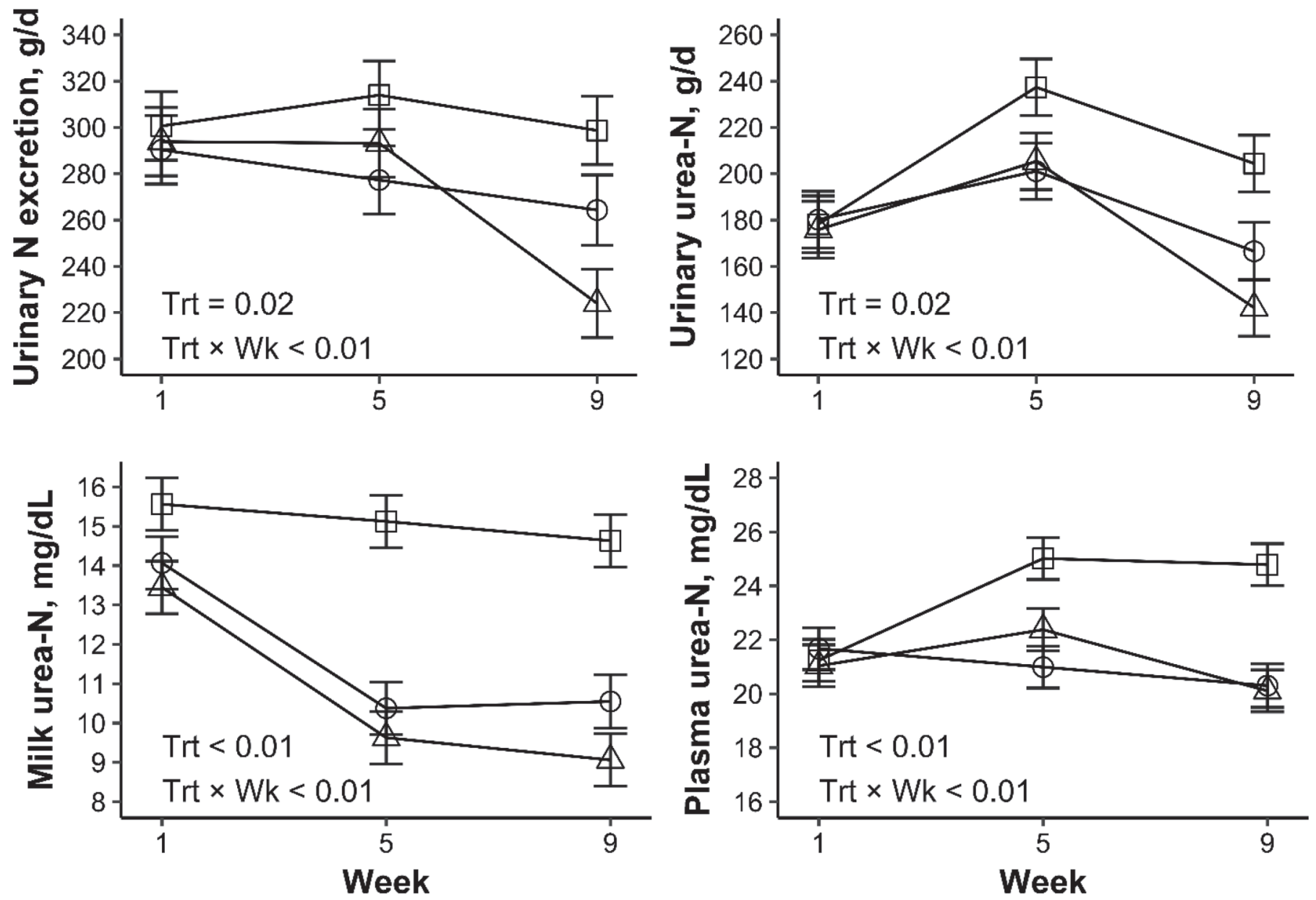

Figure 1. Nitrogen excretion and utilization during the 9-wk experimental period with control (CON), $28.8 \%$ reduced-fat distillers grains (POET Nutrition Inc., Sioux Falls, SD; DG), or DG with monensin (DGMon) diets (Trt = overall diet effect; Trt $\times$ Wk $=$ interaction of Trt by week). Means are LSM with error bars indicating SEM.

tion is not an appropriate indicator for P status of dairy cows, an increase in plasma inorganic $\mathrm{P}$ concentration and urinary $\mathrm{P}$ excretion generally occur (Knowlton and Herbein, 2002; Zhang et al., 2016) with increased P intake. Therefore, feeding a diet with RFDG at $28.8 \%$ (DM basis) can significantly increase manure $\mathrm{P}$ concentration, even though supplemental mineral $\mathrm{P}$ is removed from the ration, causing potential concerns of high $\mathrm{P}$ supply with losses from manure after field application (Ebeling et al., 2002). No difference in milk P secretion among treatments is in agreement with Knowlton and Herbein (2002). Shennan and Peaker (2000) suggested that milk $\mathrm{P}$ secretion is highly associated with lactose production, because inorganic $\mathrm{P}$ is generated during lactose synthesis and is subsequently sequestered in milk. In the current study, milk lactose yield was similar between DG versus CON (Morris et al., 2018).
Counter to our hypothesis, the addition of monensin to the DG diet (i.e., DGMon) did not affect $\mathrm{P}$ utilization and excretion compared with DG. Previously, monensin decreased fecal excretion of $\mathrm{P}$ via increased apparent digestibility and increased $\mathrm{P}$ retention in growing beef cattle (Starnes et al., 1984) or sheep (Greene et al., 1986). In these experiments, dietary $\mathrm{P}$ concentrations ( $0.45 \%$ of dietary DM) and monensin dosage rates ( 0.80 and $0.56 \mathrm{mg} / \mathrm{kg}$ of $\mathrm{BW}$, respectively) were similar to the current study $(0.45 \%$ and $0.68 \mathrm{mg} /$ $\mathrm{kg}$ of BW, respectively). The reason for the discrepancy between the current study and the previous studies is not known. However, the route of $\mathrm{P}$ excretion changes from feces to urine when diets are switched from high fiber to high concentrate (Spears and Weiss, 2014). Indeed, previous studies used high-concentrate diets for steers $(74 \%$ in diet DM) and sheep ( $71 \%$ of diet DM) 
Table 6. Effects of feeding reduced-fat corn distillers grains (RFDG) with or without monensin on P and S excretion

\begin{tabular}{|c|c|c|c|c|c|c|}
\hline \multirow[b]{2}{*}{ Item } & \multicolumn{3}{|c|}{$\operatorname{Diet}^{1,2}$} & \multirow[b]{2}{*}{ SEM } & \multicolumn{2}{|c|}{$P$-value ${ }^{3}$} \\
\hline & $\mathrm{CON}$ & DG & DGMon & & DG & Mon \\
\hline \multicolumn{7}{|l|}{ Phosphorus } \\
\hline Intake, $\mathrm{g} / \mathrm{d}^{4}$ & 93.3 & 122.6 & 113.8 & 4.28 & $<0.01$ & 0.11 \\
\hline \multicolumn{7}{|c|}{ Secretion and excretion, $\mathrm{g} / \mathrm{d}$} \\
\hline Feces $^{4}$ & 46.9 & 69.3 & 64.4 & 3.96 & $<0.01$ & 0.36 \\
\hline Urine $^{4}$ & 0.3 & 4.5 & 7.0 & 1.44 & 0.054 & 0.24 \\
\hline Total excreta ${ }^{4}$ & 47.2 & 74.2 & 71.3 & 3.29 & $<0.01$ & 0.50 \\
\hline Milk & 40.4 & 39.3 & 36.4 & 2.02 & 0.58 & 0.13 \\
\hline Retained & 5.7 & 9.0 & 6.1 & 1.26 & 0.04 & 0.07 \\
\hline \multicolumn{7}{|c|}{ As proportion of $\mathrm{P}$ intake, $\%$} \\
\hline Feces & 50.3 & 56.1 & 55.3 & 2.14 & 0.06 & 0.78 \\
\hline Urine $^{4}$ & 0.4 & 3.8 & 6.5 & 1.38 & 0.09 & 0.18 \\
\hline Total excreta ${ }^{4}$ & 50.6 & 60.3 & 61.8 & 1.45 & $<0.01$ & 0.41 \\
\hline Milk $^{4}$ & 43.3 & 32.4 & 32.1 & 1.56 & $<0.01$ & 0.87 \\
\hline Retained & 6.1 & 7.4 & 6.1 & 1.15 & 0.35 & 0.34 \\
\hline \multicolumn{7}{|l|}{ Sulfur } \\
\hline Intake, $\mathrm{g} / \mathrm{d}^{4}$ & 54.1 & 104.5 & 98.7 & 3.57 & $<0.01$ & 0.22 \\
\hline \multicolumn{7}{|c|}{ Secretion and excretion, $\mathrm{g} / \mathrm{d}$} \\
\hline Feces & 22.8 & 26.6 & 24.9 & 1.19 & 0.02 & 0.29 \\
\hline Urine $^{4}$ & 17.3 & 63.1 & 60.3 & 2.02 & $<0.01$ & 0.29 \\
\hline Total excreta ${ }^{4}$ & 40.0 & 89.6 & 85.2 & 2.99 & $<0.01$ & 0.24 \\
\hline Milk & 13.4 & 13.5 & 12.7 & 0.61 & 0.84 & 0.17 \\
\hline Retained & 0.7 & 1.4 & 0.7 & 1.43 & 0.71 & 0.70 \\
\hline \multicolumn{7}{|c|}{ As proportion of $\mathrm{S}$ intake, $\%$} \\
\hline Feces & 42.0 & 25.3 & 24.9 & 0.48 & $<0.01$ & 0.51 \\
\hline Urine $^{4}$ & 31.9 & 60.5 & 61.4 & 1.62 & $<0.01$ & 0.69 \\
\hline Total excreta ${ }^{4}$ & 74.0 & 85.9 & 86.3 & 1.58 & $<0.01$ & 0.82 \\
\hline Milk & 24.7 & 12.9 & 13.0 & 0.53 & $<0.01$ & 0.96 \\
\hline Retained & 1.3 & 1.2 & 0.7 & 1.89 & 0.97 & 0.81 \\
\hline
\end{tabular}

${ }^{1} \mathrm{CON}=$ control diet; DG $=$ diet containing $28.8 \%$ RFDG (DM basis); DGMon = DG with monensin at 20 $\mathrm{mg} / \mathrm{kg}$ of DM.

${ }^{2}$ Least squares means; largest SE of treatment mean is shown.

${ }^{3} \mathrm{DG}=\mathrm{CON}$ vs. DG; Mon $=$ DG vs. DGMon.

${ }^{4}$ Treatment $\times$ week interaction $(P<0.03)$.

compared with $44 \%$ in the current study. Therefore, the interaction of monensin with dietary $\mathrm{P}$ on absorption and utilization might be dependent upon types of diet. More studies are required to confirm the effects of monensin in relation to dietary forage-to-concentrate ratios on $\mathrm{P}$ utilization and retention.

Interactions of treatment by week for $\mathrm{P}$ intake, fecal $\mathrm{P}$ excretion (Figure 2), and urinary $\mathrm{P}$ excretion $(P \leq$ $0.02)$ were observed. The interactions occurred due to large decreases in these variables in wk 9 for DGMon. The decreases in wk 9 for DGMon were a consequence of decreased P intake. Intake of P for DG and DGMon decreased gradually compared with $\mathrm{CON}$ as the experiment progressed (treatment $\times$ wk, $P<0.01$; Figure 2), where the degree of decreases in $\mathrm{P}$ intake was greater for DGMon compared with DG.

\section{Sulfur Utilization and Excretion}

Compared with CON, feeding cows the DG diet increased $(P \leq 0.02) \mathrm{S}$ intake and fecal and urinary excretion by 93,17 , and $265 \%$, respectively (Table $6)$. Urinary $\mathrm{S}$ excretion as proportion of $\mathrm{S}$ intake also increased $(P<0.01)$ for cows fed DG compared with CON. As a result, total excretion of $\mathrm{S}$ was greater (89.6 vs. $40.0 \mathrm{~g} / \mathrm{d} ; P<0.01)$ for cows fed DG versus CON. However, milk $\mathrm{S}$ secretion did not differ $(P=$ 0.84 ), and as a result, milk S efficiency (milk S secretion as proportion of $\mathrm{S}$ intake) decreased $(P<0.01)$ for cows fed the DG compared with CON diet. Apparent total-tract S digestibility increased (74.7 vs. $58.0 \%$; $P<0.01)$ for cows fed the DG compared with CON diet (Table 4). Furthermore, plasma total S increased (115.7 vs. $110.2 \mathrm{mg} / \mathrm{dL}$ ), and plasma sulfate (4.5 vs. $3.5 \mathrm{mg} / \mathrm{dL})$ was greater $(P \leq 0.03)$ for DG versus CON (Table 5). However, monensin supplementation to the DG diet did not affect $\mathrm{S}$ utilization and excretion in the current study.

Increased $\mathrm{S}$ excretion with increasing $\mathrm{S}$ intake for cows fed DG versus CON was expected. Although S intake increased both fecal and urinary $\mathrm{S}$ excretion, the degree of increase in urinary $\mathrm{S}$ excretion was consider- 
CON O DG $\triangle$ DGMon
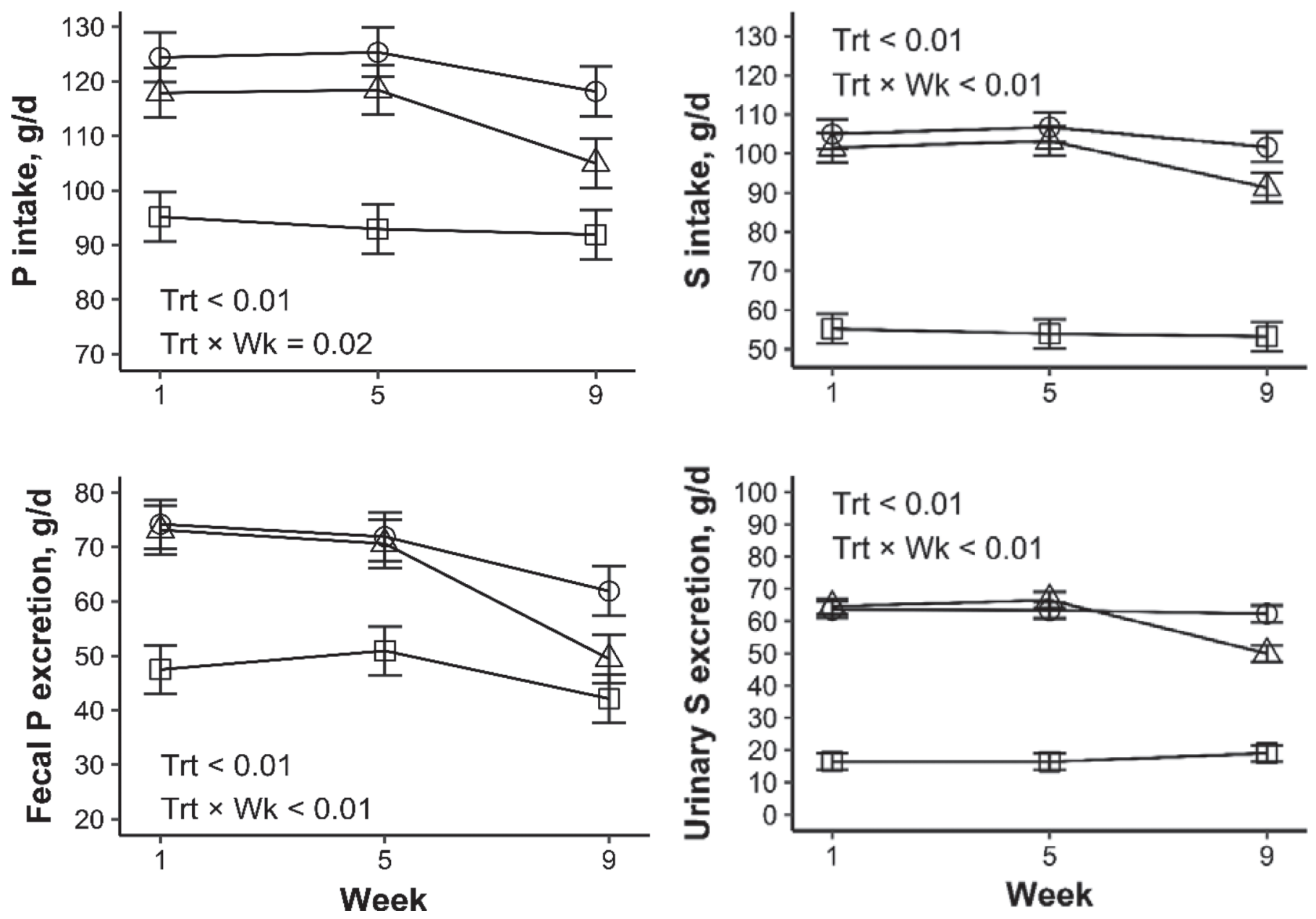

Figure 2. Phosphorus and sulfur excretion and utilization during the 9-wk experimental period with control (CON), $28.8 \%$ reduced-fat distillers grains (POET Nutrition Inc., Sioux Falls, SD; DG), or DG with monensin (DGMon) diets $($ Trt $=$ overall diet effect; Trt $\times$ Wk $=$ interaction of Trt by week). Treatment by week interactions were also observed for other variables about $\mathrm{P}$ and $\mathrm{S}$ utilization and excretion but not presented because trends were similar to current graphs. Means are LSM with error bars indicating SEM.

ably greater than fecal $\mathrm{S}$ excretion. An increase in $\mathrm{S}$ intake has been reported to increase urinary $\mathrm{S}$ excretion in beef cattle fed high-DDGS diets (Spiehs and Varel, 2009; Salim et al., 2012; Li et al., 2014) and in dairy cows fed supplemental inorganic $\mathrm{S}\left(\mathrm{MgSO}_{4}\right.$; Tebbe et al., 2018). However, milk $\mathrm{S}$ secretion was not affected by treatments, in agreement with Tebbe et al. (2018), who found increased dietary $\mathrm{S}$ content by inclusion of $\mathrm{MgSO}_{4}$ did not affect milk S secretion. This suggests that mammary uptake of $\mathrm{S}$ is likely independent of plasma S status.

We observed no effects of adding monensin to the DG diet except that total plasma $S$ concentration decreased (109.8 vs. $115.7 \mathrm{mg} / \mathrm{dL} ; P=0.02)$. Plasma total $\mathrm{S}$ concentration can be affected by several factors, such as $\mathrm{S}$ intake, $\mathrm{S}$ absorption in the rumen (inorganic
S) and small intestine (microbial S), and inhaling $\mathrm{H}_{2} \mathrm{~S}$ produced from the rumen. We expected monensin to alter rumen microbial populations and possibly decrease ruminal $\mathrm{H}_{2} \mathrm{~S}$ production (Felix and Loerch, 2011). Although microbial populations were not examined, a lack of difference in milk fatty acid profile (Morris et al., 2018) indicates minimal effects of monensin on altering microbial population and fermentation in the rumen.

A treatment $\times$ week interaction $(P<0.01)$ for urinary $\mathrm{S}$ excretion occurred where DGMon decreased urinary $\mathrm{S}$ excretion in wk 9 compared with DG. The decreases in urinary $\mathrm{S}$ excretion for DGMon versus DG in wk 9 can be also explained by gradual decreases (treatment $\times$ week, $P<0.01$; Figure 2 ) in $\mathrm{S}$ intake as the experiment progressed. 
It is worth noting that apparent total-tract NDF digestibility decreased $(P<0.01)$ for cows fed the DG versus CON diet (47.4 vs. 53.5; Table 4). Feeding a diet with $2.6 \%$ sulfate negatively affected rumen microbial growth and fermentation (van Zijderveld et al., 2010). In an in vitro study, increased S decreased cellulose digestion (Hubbert et al., 1958). Additionally, the source of fiber likely contributed to the difference in NDF digestibility between CON and DG. In the current study, the major difference in fiber sources originated from RFDG replacing soyhulls in CON for DG. Firkins (1997) reported the ruminal digestibility of NDF for DDGS and soyhulls were 71.6 and $90.7 \%$, respectively.

\section{CONCLUSIONS}

Inclusion of RFDG at $28.8 \%$ of diet DM by replacing mainly SBM in a dairy ration did not affect dietary $\mathrm{CP}$ content and total $\mathrm{N}$ intake. However, feeding a high-RFDG diet decreased urinary $\mathrm{N}$ excretion without differences in fecal $\mathrm{N}$ excretion. The RFDG diet increased dietary concentrations of dietary $\mathrm{P}$ and $\mathrm{S}$ contents, resulting in increases in $\mathrm{P}$ and $\mathrm{S}$ excretion in feces and urine. Supplementation of monensin to a high-RFDG diet did not have major effects on N, $\mathrm{P}$, and $\mathrm{S}$ utilization and excretion compared with the RFDG diet without monensin. However, an increase in $\mathrm{N}$ digestibility was observed for cows fed a high-RFDG diet with monensin. The current study suggests that feeding RFDG at $28.8 \%$ (DM basis) as a replacement for mainly SBM can decrease urinary $\mathrm{N}$ excretion, potentially lowering ammonia emissions from manure; however, large increases in fecal and urinary $\mathrm{P}$ and $\mathrm{S}$ excretion with the high-RFDG diet may increase environmental concerns (e.g., $\mathrm{P}$ runoff and $\mathrm{H}_{2} \mathrm{~S}$ emissions from manure).

\section{ACKNOWLEDGMENTS}

The authors thank P. A. Dieter and L. R. Rebelo (The Ohio State University, Wooster) for assistance with sample collection and laboratory analysis, and the Krauss Dairy Farm staff for care of the experimental animals. Research was partially funded from Hatch funds administered by USDA, the Ohio Dairy Research Fund, and state and federal funds appropriated to the Ohio Agricultural Research and Development Center, The Ohio State University.

\section{REFERENCES}

Alvarez-Fuentes, G., J. A. Appuhamy, and E. Kebreab. 2016. Prediction of phosphorus output in manure and milk by lactating dairy cows. J. Dairy Sci. 99:771-782.
Andriamanohiarisoamanana, F. J., Y. Sakamoto, T. Yamashiro, S. Yasui, M. Iwasaki, I. Ihara, O. Tsuji, and K. Umetsu. 2015. Effects of handling parameters on hydrogen sulfide emission from stored dairy manure. J. Environ. Manage. 154:110-116.

AOAC International. 2000. Official Methods of Analysis. Vol. 1 and 2. 17th ed. AOAC International, Gaithersburg, MD.

Bussink, D., and O. Oenema. 1998. Ammonia volatilization from dairy farming systems in temperate areas: a review. Nutr. Cycl. Agroecosyst. 51:19-33.

Castillo-Lopez, E., H. A. Ramirez Ramirez, T. J. Klopfenstein, D. Hostetler, K. Karges, S. C. Fernando, and P. J. Kononoff. 2014. Ration formulations containing reduced-fat dried distillers grains with solubles and their effect on lactation performance, rumen fermentation, and intestinal flow of microbial nitrogen in Holstein cows. J. Dairy Sci. 97:1578-1593.

Chen, G., and J. Russell. 1989. More monensin-sensitive, ammoniaproducing bacteria from the rumen. Appl. Environ. Microbiol. $55: 1052-1057$.

DuFour, E. I. 2017. Advancing chemical characterization of feedstuffs commonly included in dairy cow rations. MS Thesis. University of Nebraska, Lincoln, NE. https://digitalcommons.unl.edu/ animalscidiss $/ 146$

Ebeling, A. M., L. G. Bundy, J. M. Powell, and T. W. Andraski. 2002. Dairy diet phosphorus effects on phosphorus losses in runoff from land-applied manure. Soil Sci. Soc. Am. J. 66:284-291.

Eriksson, T., and B. O. Rustas. 2014. Effects on milk urea concentration, urine output, and drinking water intake from incremental doses of potassium bicarbonate fed to mid-lactation dairy cows. J. Dairy Sci. 97:4471-4484.

Felix, T. L., and S. C. Loerch. 2011. Effects of haylage and monensin supplementation on performance, carcass characteristics, and ruminal metabolism of feedlot cattle fed diets containing $60 \%$ dried distillers grains. J. Anim. Sci. 89:2614-2623.

Felix, T. L., N. A. Pyatt, and S. C. Loerch. 2012. Effects of monensin supplementation on ruminal metabolism of feedlot cattle fed diets containing dried distillers grains. J. Anim. Sci. 90:3905-3913.

Firkins, J. L. 1997. Effects of feeding nonforage fiber sources on site of fiber digestion. J. Dairy Sci. 80:1426-1437.

Foth, A. J., T. Brown-Brandl, K. J. Hanford, P. S. Miller, G. Garcia Gomez, and P. J. Kononoff. 2015. Energy content of reduced-fat dried distillers grains with solubles for lactating dairy cows. J. Dairy Sci. 98:7142-7152.

Gehman, A. M., and P. J. Kononoff. 2010. Utilization of nitrogen in cows consuming wet distillers grains with solubles in alfalfa and corn silage-based dairy rations. J. Dairy Sci. 93:3166-3175.

Greene, L. W., G. Schelling, and F. Byers. 1986. Effects of dietary monensin and potassium on apparent absorption of magnesium and other macroelements in sheep. J. Anim. Sci. 63:1960-1967.

Guidotti, T. L. 2010. Hydrogen sulfide: Advances in understanding human toxicity. Int. J. Toxicol. 29:569-581.

Hanrahan, L. P., W. E. Jokela, and J. R. Knapp. 2009. Dairy diet phosphorus and rainfall timing effects on runoff phosphorus from land-applied manure. J. Environ. Qual. 38:212-217.

Hubbert, F., E. Cheng, and W. Burroughs. 1958. Mineral requirement of rumen microorganisms for cellulose digestion in vitro. J. Anim. Sci. $17: 559-568$.

Isaac, R. A., and W. C. Johnson. 1985. Elemental analysis of planttissue by plasma emission-spectroscopy - Collaborative study. J. Assoc. Off. Anal. Chem. 68:499-505.

Jones, J., B. Wolf, and H. Mills. 1991. Microwave Digestion Using CEM Microwave Digestion System. Plant Analysis Handbook. Micro-Macro Publishing. Athens, GA.

Knowlton, K. F., and J. Herbein. 2002. Phosphorus partitioning during early lactation in dairy cows fed diets varying in phosphorus content. J. Dairy Sci. 85:1227-1236.

Larsen, M., C. Galindo, D. R. Ouellet, G. Maxin, N. B. Kristensen, and H. Lapierre. 2015. Abomasal amino acid infusion in postpartum dairy cows: Effect on whole-body, splanchnic, and mammary amino acid metabolism. J. Dairy Sci. 98:7944-7961.

Lee, C., A. N. Hristov, T. W. Cassidy, K. S. Heyler, H. Lapierre, G. A. Varga, M. J. de Veth, R. A. Patton, and C. Parys. 2012. Rumen- 
protected lysine, methionine, and histidine increase milk protein yield in dairy cows fed a metabolizable protein-deficient diet. J. Dairy Sci. 95:6042-6056.

Li, Y. L., K. A. Beauchemin, T. A. McAllister, and W. Z. Yang. 2014 Intakes and excretion route of nitrogen, phosphorous and sulfur by finishing beef heifers fed increasing levels of wheat dried distillers grains with solubles to substitute for barley grain and barley silage. Livest. Sci. 170:43-52.

Martineau, R., C. Benchaar, H. V. Petit, H. Lapierre, D. R. Ouellet, D. Pellerin, and R. Berthiaume. 2007. Effects of lasalocid or monensin supplementation on digestion, ruminal fermentation, blood metabolites, and milk production of lactating dairy cows. J. Dairy Sci. 90:5714-5725.

Mjoun, K., K. F. Kalscheur, A. R. Hippen, and D. J. Schingoethe 2010a. Ruminal degradability and intestinal digestibility of protein and amino acids in soybean and corn distillers grains products. J. Dairy Sci. 93:4144-4154.

Mjoun, K., K. F. Kalscheur, A. R. Hippen, D. J. Schingoethe, and D. E. Little. 2010b. Lactation performance and amino acid utilization of cows fed increasing amounts of reduced-fat dried distillers grains with solubles. J. Dairy Sci. 93:288-303.

Morris, D. L., S. H. Kim, P. J. Kononoff, and C. Lee. 2018. Continuous 11-week feeding of reduced-fat distillers grains with and without monensin reduces lactation performance of dairy cows. J. Dairy Sci. In press.

Morse, D., H. H. Head, C. J. Wilcox, H. H. Van Horn, C. D. Hissem, and B. Harris. 1992. Effects of concentration of dietary phosphorus on amount and route of excretion. J. Dairy Sci. 75:3039-3049.

Nennich, T. D., J. Harrison, L. VanWieringen, N. St-Pierre, R. Kincaid, M. Wattiaux, D. Davidson, and E. Block. 2006. Prediction and evaluation of urine and urinary nitrogen and mineral excretion from dairy cattle. J. Dairy Sci. 89:353-364.

Nousiainen, J., K. Shingfield, and P. Huhtanen. 2004. Evaluation of milk urea nitrogen as a diagnostic of protein feeding. J. Dairy Sci. $87: 386-398$.

NRC. 2001. Nutrient Requirements of Dairy Cattle. 7th rev. ed. Natl. Acad. Sci., Washington, DC.

Pinheiro, J., D. Bates. S. DebRoy, D. Sarkar, and R Core Team. 2017. nlme: Linear and nonlinear mixed effects models: Version 3.1-131. Accessed Jan. 18, 2018. https://CRAN.R-project.org/package= nlme.

Plaizier, J. C., A. Martin, T. Duffield, R. Bagg, P. Dick, and B. McBride. 2000. Effect of a prepartum administration of monensin in a controlled-release capsule on apparent digestibilities and nitrogen utilization in transition dairy cows. J. Dairy Sci. 83:2918-2925.

Ramirez-Ramirez, H. A., E. Castillo Lopez, C. J. Jenkins, N. D. Aluthge, C. Anderson, S. C. Fernando, K. J. Harvatine, and P. J. Kononoff. 2016. Reduced-fat dried distillers grains with solubles reduces the risk for milk fat depression and supports milk production and ruminal fermentation in dairy cows. J. Dairy Sci. 99:1912-1928.
Renewable Fuels Association. 2017. Ethanol industry outlook. Renewable Fuels Association, Washington, DC. Accessed Jul. 3, 2017. http://www.ethanolrfa.org/wp-content/uploads/2017/02/Ethanol -Industry-Outlook-2017.pdf.

Ruiz, R., G. Albrecht, L. Tedeschi, G. Jarvis, J. Russell, and D. Fox. 2001. Effect of monensin on the performance and nitrogen utilization of lactating dairy cows consuming fresh forage. J. Dairy Sci. 84:1717-1727.

Salim, H., K. M. Wood, M. K. Abo-Ismail, P. L. McEwen, I. B. Mandell, S. P. Miller, J. P. Cant, and K. C. Swanson. 2012. Influence of feeding increasing levels of dry corn distillers grains plus solubles in whole corn grain-based finishing diets on total tract digestion, nutrient balance, and excretion in beef steers. J. Anim. Sci. 90:4441-4448.

Shennan, D. B., and M. Peaker. 2000. Transport of milk constituents by the mammary gland. Physiol. Rev. 80:925-951.

Spears, J. W., and W. P. Weiss. 2014. Invited review: Mineral and vitamin nutrition in ruminants. Prof. Anim. Sci. 30:180-191.

Spiehs, M. J., and V. H. Varel. 2009. Nutrient excretion and odorant production in manure from cattle fed corn wet distillers grains with solubles. J. Anim. Sci. 87:2977-2984.

Starnes, S. R., J. W. Spears, M. A. Froetschel, and W. J. Croom Jr. 1984. Influence of monensin and lasalocid on mineral metabolism and ruminal urease activity in steers. J. Nutr. 114:518-525.

Suttle, N. F., and E. J. Underwood. 2010. Mineral Nutrition of Livestock. 4th ed. CABI, Wallingford, Oxfordshire, UK.

Tebbe, A. W., D. J. Wyatt, and W. P. Weiss. 2018. Effects of magnesium source and monensin on nutrient digestibility and mineral balance in lactating dairy cows. J. Dairy Sci. 101:1152-1163.

Thomsen, I. K. 2000. C and N transformations in $15 \mathrm{~N}$ cross-labelled solid ruminant manure during anaerobic and aerobic storage. Bioresour. Technol. 72:267-274.

Valadares, R. F., G. Broderick, S. Valadares Filho, and M. Clayton. 1999. Effect of replacing alfalfa silage with high moisture corn on ruminal protein synthesis estimated from excretion of total purine derivatives. J. Dairy Sci. 82:2686-2696.

van Zijderveld, S. M., W. J. J. Gerrits, J. A. Apajalahti, J. R. Newbold, J. Dijkstra, R. A. Leng, and H. B. Perdok. 2010. Nitrate and sulfate: Effective alternative hydrogen sinks for mitigation of ruminal methane production in sheep. J. Dairy Sci. 93:5856-5866.

Weiss, W. P., L. B. Willett, N. R. St-Pierre, D. C. Borger, T. R. McK elvey, and D. J. Wyatt. 2009. Varying forage type, metabolizable protein concentration, and carbohydrate source affects manure excretion, manure ammonia, and nitrogen metabolism of dairy cows. J. Dairy Sci. 92:5607-5619.

Zhang, B., C. Wang, Z. H. Wei, H. Z. Sun, G. Z. Xu, J. X. Liu, and H. Y. Liu. 2016. The effects of dietary phosphorus on the growth performance and phosphorus excretion of dairy heifers. Asian-Australas. J. Anim. Sci. 29:960-964 